\title{
UNITED NATIONS LAW IN AFRICA: THE CONGO OPERATION AS A CASE STUDY
}

\author{
Thomas M. Franck*
}

\section{INTRODUCTION}

The United Nations Operation in the Congo (ONUC) is not a mutant: its pedigree boasts such formidable progenitors as the Korean Unified Command, the Palestine Truce Supervisory Organization, the United Nations Middle East Emergency Force (UNEF), and the Laos Peace Observer Group.

The common gene which united ONUC with these others is interposition: the injection of a United Nations presence to bring international law to bear in a situation of international chaos. ONUC also combines in itself other selected characteristics of its predecessors. It has inherited from UNEF the concept of an internationallyrecruited military contingent; from the Korean Command, ONUC has taken the element of mandatory decisions backed by force. The Lebanon Observation Group bequeathed it the nature of a neutral intervention.

In combining these various elements, ONUC has created for itself a unique personality: it is by far the most ambitious interposition to date in a situation characterized by haphazard decolonization, tribal warfare, and cold war pressures. A brief glance at the principal remaining "colonial" areas of Africa-Angola, Mozambique, South Africa, and Southern Rhodesia-unfortunately does not induce the comforting thought that this uniqueness will be perpetual.

Should the need arise again in any of these other "colonial" areas would the world turn once more to the United Nations? The answer, in part weighted by fear of the alternatives, will largely depend on the assessment the world, and particularly the African states themselves, make of the role played by the United Nations in the Congo.

Since ONUC has been carefully and constantly governed by expressed law, and since it has by its deliberate choice and application of precedent and its recourse to reasoned innovation also made law, a fair assessment of its impact on the Congo must be weighed not only on the scale of politics but also of law.

\section{Legal Basis for the United Nations Presence}

Even while the ritual jollifications of independence were still under way, the tender plant of national responsibility was being trampled underfoot by inexperienced and undisciplined elements in the new state. King Baudouin proclaimed the Congo

* B.A. 1952, LL.B. I953, University of British Columbia; LL.M. 1954, S.J.D. 1959, Harvard University. Professor of Law, New York University. Author, Race and Nattonalism-The Struggle for Power in Rhodesta-Nyasaland (1960). 
independent on Thursday, June 30, I96o. Exactly two weeks thereafter, the United Nations Security Council had already passed its first Congo resolution; and thirtysix hours later, the first of the ONUC contingents began taking up positions under the Blue and White flag.

Violence had broken out on July 2 in the vicinities of Léopoldville and Luluabourg, and three days later the mutiny of the Congolese army (the ANC) was in full cry. Of all the components of Congolese self-government, the ANC was the most precarious link in an ill-forged chain. Discipline was harsh, pay low, andsince no Congolese had ever been commissioned-incentives were utterly lacking. The predominantly Flemish command made as scant effort to hide their scorn for the Congolese as for the Belgian politicians. Yet the pre-emptory discharge of all Belgian officers on July 8 had the explosive effect of suddenly lifting the lid from an overheated pressure cooker. As the rampaging army both provoked and then forcibly halted the flight of thousands of whites, Belgian troops began to fan out from their two bases of Kamina and Kitona, and additional paratroopers were brought in by air.

In the context of the confusion which prevailed in the Congo during July, it would be surprising if the legal image of Belgian intervention were to emerge clearly. In the retrospective opinion of the present Government of the Congo, "only the Minister of Defense, at that time Mr. Patrice Lumumba, had the authority, by virtue of the Belgian-Congolese General Treaty of Friendship, Assistance and Cooperation, to make an appeal for the military intervention of the Belgian troops."1

No such appeal was made. M. Lumumba did, at one point, it appears, "agree in principle that the Belgian metropolitan troops operating in Luluabourg can remain for at least two months ..."2 but only under certain conditions. Moreover, the agreement-if it were such-did not cover the more extensive Belgian interventions at Elizabethville ${ }^{3}$ and elsewhere. Indeed, the Congolese Government on the very same day requested United States troops to counteract the Belgian intervention. When this direct assistance was refused, they turned to the United Nations in accordance with the suggestion that accompanied the United States rejection.

In a communication addressed to the Secretary General on July I2, I960, President Kasavubu and Prime Minister Lumumba requested the "dispatch by the United Nations of military assistance . . to protect the national territory of the Congo against the present external aggression which is a threat to world peace," an element

\footnotetext{
${ }^{1}$ Republic of the Congo, Ministry of Foreign Affairs, Document Division, The Province of the Katanga AND Congolese Independence 17 (1962). The treaty was never ratified by the Congolese Chambers and was later denounced by the Government of the Congo.

${ }^{2}$ Letter from M. Lumumba to the Belgian Consul General in Luluabourg, July II, I960, id. at I7-r8.

${ }^{3}$ Katanga had, on July II, proclaimed its secession, and $M$. Tshombe, as its Prime Minister, had not only requested but demanded the dispatch of Belgian troops to Elizabethville. Id. at I8-21.

"Interview with Dr. Oscar Schachter, legal counsel to the U.N. Acting Secretary-General, New York, N.Y., April 30, 1962 .
} 
of which is " $a$ conspiracy between Belgian imperialists and a small group of Katanga leaders" to perpetrate "the secession of Katanga ... which means the disguised perpetuation of colonialist regime."s

The Congolese complaint contains three distinct elements:

a) an allegation of external aggression,

b) an allegation of a conspiracy to bring about the secession of Katanga,

c) a request for United Nations military aid to bring an end to both these alleged infractions of Congolese sovereignty.

As a "party to a dispute" the Congo could, even though it was not at the time a member of the United Nations, ${ }^{6}$ itself bring a complaint before the Security Council under terms of article $35(2)$ of the Charter. In choosing not to do so, the Congo instead requested the Secretary General to proceed for the first time on his own initiative under article ninety-nine, whereby he "may bring to the attention of the Security Council any matter which in his opinion may threaten the maintenance of international peace and security." This obviated a jurisdictional decision as to whether a "dispute" or "situation" existed since his mere belief to that effect is sufficient to create initial jurisdiction.

On July 13 , 1960, therefore, the Secretary General circulated the following memorandum: ${ }^{7}$

I wish to inform you that I have to bring to the attention of the Security Council a matter which, in my opinion, may threaten the maintenance of international peace and security. Thus, I request you to call an urgent meeting of the Security Council to hear a report of the Secretary-General on a demand for United Nations action in relation to the Republic of the Congo.

May I suggest that the meeting is called for tonight at 8:30 p.m.

That evening, the Secretary General outlined to the hurriedly convened Security Council the framework of a proposed United Nations intervention. His efforts were spurred by a further communication from the Congolese President and Prime Minister threatening that if military assistance was not received without delay, the Republic of the Congo would be obliged to appeal to the Bandung Treaty Powers ${ }^{8}$ a euphemism for Chinese "volunteers." The Secretary General's charge to the Council classified the presence of Belgian troops in the Congo as "a source of internal,

- U.N. Securury Council Off. Rec. I5th year, Supp. July-Sept. 1960, at Ix (S/4382) (1960).

- United Nations membership had been requested on July 1 , by Prime Minister Lumumba (U.N. Dac. No. S/436I) and had received immediate Security Council approval (U.N. Doc. No. S/4377). However, the General Assembly did not act on the application until it met in the fall. Resolutions of the Fifteenth Session, Vol. 2, U.N. Doc. No. 1480 (XV), Admission of the Republic of the Congo (Léopoldville) to Membership in the United Nations (Item 20), Doc. A/L 599, Sept. 20, 1960, U.N. GEN. Ass. Opr. Rzc. 15th Sess., Supp. No. $16(A / 4684)$ at $6_{4}(1960)$.

${ }^{2}$ U.N. Doc. No. S/438r.

- Annual Report of the Secretary General on the Work of the Organization, June 16, 1960-June 16, 1961, U.N. GeN. Ass. Ofr. Rec. I6th Sess., Supp. No. I, at I (A/4800) (1961) [hereinafter cited as Annuar Report]. See also U.N. Doc. No. S/4382, at 2. 
and potentially also of international tension" and urged their replacement by "technical assistance of a military nature."

The earnest discussion continued through the night. Early on Thursday morning the Security Council adopted a resolution introduced by Tunisia but generally reflecting the Secretary General's views. ${ }^{10}$ No negative votes were cast, but China, France, and the United Kingdom abstained out of deference to the views of Belgium. ${ }^{11}$

In his appearance before the Security Council the Secretary General had suggested the following: (I) the dispatch of a military force; (2) the standards for its formation; (3) the limitations on its function. The most important elements of (3) were that the proposed force not be allowed to act in any way likely to make it a party to internal conflicts or to use force except in self-defense. ${ }^{12}$

The July I4 resolution of the Security Council incorporates both the KasavubuLumumba request of July I2 and the Secretary General's appeal of July I3 in its terms, ${ }^{13}$ and, in the words of the Secretary General, his statement to the Council "may be regarded as a basic document on the interpretation of the mandate."14 Yet that statement is not entirely reconcilable with the Kasavubu-Lumumba request, for the latter distinctly invites help against the "conspiracy between Belgian imperialists and a small group of Katangese leaders" while the former excludes the use of force in anything but self-defense and abjures all intervention in domestic disputes.

This latent contradiction was not at first apparent. The Secretary General, in postulating the principle of "neutral" intervention, proceeded in accordance with the working principles he had formulated for the Lebanon Observation Group in

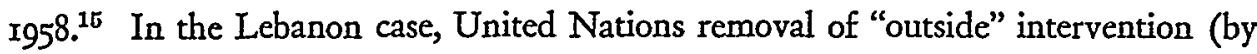
the United States and infiltrators from neighboring states) had been sufficient to retire that case from the list of active "situations." In the Congo, this happy consequence was similarly expected to follow: the removal of Belgian and other foreign intervention was expected to end the danger of the "Katanga conspiracy" and civil war. In fact, however, it did not; and when it became apparent very soon that some of the deepest roots of the Congo crisis were sunk in purely Congolese soil, and that

- Annual Refort i. See also U.N. Secumity Council Off. Rec. 15th year, 873d meeting i1-iz (S/PV. 873) (1960).

${ }_{10}$ U.N. Doc. No. S/4387. Resolution as submitted by Tunisia, S/4383, adopted July I3, Ig6o (same text as $S / 4387$ ).

${ }^{12}$ ANNUAL Report 2.

18 "The Security Council, considering the report of the Secretary-General on a request for the United Nations action in relation to the Republic of the Congo, considering the request for military assistance addressed to the Secretary-General by the President and the Prime Minister of the Republic of the Congo ....."

${ }^{14}$ First Report by the Secretary-General on the Implementation of the Security Council Resolution of July X4, 1960 (S/4387) at I, U.N. SEcusurt Councri Opr. REC. 15th year, Supp. July-Sept, I960, at 16 (S/4389 and Add. I-6 (1960) [hereinafter cited as First Ruponr].

${ }^{18} \mathrm{Sec}$ Annual Report of the Seeretary-General on the Work of the Organization, June I6, x958-June 15, 1959, U.N. GEN. Ass. OpP. REG. 15th Sess., Supp. No. 3y at 15-22 (A/4132) (1959). 
they were yet sufficient to sustain a sinister tree that cast an international shadow, the dichotomy between "help against internal conspiracy" and "neutrality in internal conflicts" became an acute problem for the United Nations.

Nor did the terms of the July 14 resolution ${ }^{16}$ help to clarify matters. Besides incorporating the Kasavubu-Lumumba and Hammarskjold submissions, it did two things: ( $\mathrm{r}$ ) called on Belgian troops to withdraw, and (2) authorized military assistance to the Government of the Congo in consultation with that Government until in the opinion of that Government its forces were able to meet the task of preserving national security.

- What was the United Nations' role: neutrality or the active rendering of military assistance to the Government. of the Congo to preserve national security against secessionists? The problem was barely discernible on July I4, although Katanga had proclaimed its independence already on July $\mathrm{rr}^{17}$

The vagueness of the resolution of July $\mathrm{I} 4, \mathrm{x} 960$, and the subsequent mandates of the Security Council, which in the words of the President of the General Assembly imposed "an intolerable burden of interpretation and discretion" on the Secretary-General, are due to a number of factors. Were these resolutions subject to the stringent test of the Schechter case, ${ }^{18}$ they would almost certainly be void for vagueness. Yet such sweeping delegation is scarcely the unique experience of the Congo Operation. When the General Assembly some four years earlier decided to establish the United Nations Emergency Force (UNEF), it was by an even more standard-less mandate to the Secretary-General. The resolution of November 2, r $956,{ }^{19}$

... requests, as a matter of priority, [the Secretary-General] to submit . . . within 48 hours a plan for the setting up, with the consent of the nations concerned, of an emergency international United Nations Force to secure and supervise the cessation of hostilities in accordance with all the terms of the aforementioned resolution.

The same resolution also "authorizes the Secretary-General immediately to arrange with the parties concerned for the implementation of the cease-fire and the halting of the movement of military forces and arms into the area ..." and "to obtain compliance of the withdrawal of all forces behind the armistice lines." the Emergency Force to be set up? What was to be the standard and rate of withdrawal? What points of interposition (such as that at Shaarm el Shiek on the Gulf of Akaba) were the United Nations to occupy? It was all left for the SecretaryGeneral to determine.

${ }^{10}$ U.N. Doc. No. S/4383.

${ }^{17}$ For a discussion of the domestic constitutionality of this act see The Province of Katanon AND Congolese IndePendence, op. cit. supra note I, at 18-22. See also the discussion of articles 110 and 214 of the Loi Fondamentale in the light of political events contained in Thomas M. Franck \& John Carex, The Role of the United Nations in the Congo-A Retrospective Perspective (1962).

${ }^{28}$ Schechter Poultry Corp. v. United States, 295 U.S. 495 (1935).

${ }^{10}$ Resolution 998, Gev. Ass. OfF. Rec. Ist Emergency Special Sess., Supp. No. I, at 2 (A/3354) (1956).

${ }_{20}$ Resolution 999, ibid. 
What are the causes of this vagueness? Certainly. it is not a matter of bad drafting, although resolutions do sometimes reflect the haste in which they are born. More important is an element equally responsible for vagueness in congressional enactments: the expediency of compromise.

Immediately after the vote on the July I4 resolution, the Soviet Union and Poland announced that they had voted for the text because its principal object was to effect the immediate withdrawal of the Belgians. The United States declared that it had voted for the resolution because it made provision for technical assistance to law and order but that they doubted the wisdom of calling for Belgian withdrawal. In implementing the resolution, the United States stated, the Secretary General "must not . . . contribute to the perpetuation of public disorder by insisting upon the withdrawal of military units capable of assisting in the protection of life and property without the establishment of other methods to accomplish that task"-a direct contradiction of the Soviet interpretation that at once presented a dilemma to the Secretary-General ${ }^{21}$ which could not be papered over by reference to the vague text of the resolution itself.

Yet vagueness of language may be the only way to get action at all: a word formula deferring the really difficult decisions to the course of events and the discretion of the administrators. In many instances this is a good thing. As in the regulation of new domestic problems-the allocation of television channels, for example-a more vaguely delegated standard of administration may be necessary to allow room for ad hoc solutions to unpredictable problems. Vague delegation may also be useful in shifting to anonymous administrative officials the task of making decisions generally regarded as necessary but for which some or all of the Powers do not, for political reasons, wish to take responsibility.

In this way, broad delegation helps break log jams. But it may also allow the logs to move too quickly. States may, in fact, vigorously oppose a course of action on which the Secretariat has already embarked in the honest belief that it is acting within the scope of the delegated authority. Worse, states may hypocritically support a popalar resolution with their public vote while at the same time sabotaging its execution by subterfuge in the field or in the accounting office. There are, obviously, dangers inherent in action carried out in accordance with a legal mandate that creates the illusion of agreement where none in fact exists. In the understated words of the Secretary General, ${ }^{22}$

The character of the mandates has in many cases been such that in carrying out his functions the Secretary-General has found himself forced also to interpret the decisions in the light of the Charter, United Nations precedent and the aims and intentions expressed by the members. ... . Developments have sometimes led to situations in which he has had to shoulder responsibilities for certain limited political functions.

21 Annual Report 2.

${ }^{39}$ Introduction to the Annual Report of the Secretary-General on the Work of the Organization, June 16, 1960-June 15, 196x, U.N. GeN. Ass. OFf. Rec. I6th Sess., Supp. No. IA (A/4800/Add.x) (xg6I). 
It is against this initial vagueness, compounded by later resolutions, that all legal aspects of the United Nations interposition in the Congo must be assessed.

II

\section{United Nations Jurisdiction in the Congo: Contract or Legislation?}

The previous international military action of the United Nation, UNEF, was in many ways similar to the ONUC operation. Like the Congo undertaking, UNEF was set up on a temporary emergency basis, with "no intent in the establishment of the force to influence the ... political balance. ..."23 In creating the Congo force, the Secretary General was able to lean heavily on the experience of the earlier action. ${ }^{24}$

There was, however, one clear legal difference between the inception of UNEF and that of ONUC. According to the Secretary General, UNEF functioned "on the basis of a decision reached under the terms of the resolution "Uniting for Peace," and being a creation of the General Assembly, which only has the power to make recommendations, it was, ${ }^{25}$

limited in its operation to the extent that consent of the parties concerned is required under generally recognized international law. While the General Assembly is cnabled to establish the force with the consent of those parties which contribute units to the force, it could not request for force to be stationed or operate on the territory of a given country without the consent of the Government of that country.

This consensual or contractual element was fundamental to the UNEF presence in Egypt. When it came to recruiting national contingents, "Egypt had what amounted to a veto power." ${ }^{26}$ This was demonstrated, for example, by Egypt's rejection of the Queen's Own Rifles of Canada. ${ }^{27}$ Moreover, Egyptian consent to the landing of the force had to be specifically communicated by telegram on November $\mathrm{I}_{4}^{28}$ before the first troops disembarked.

ONUC was a different breed altogether. Its authorization rested not on the General Assembly's recommendatory powers but on chapter seven of the United

${ }^{28}$ Second and Final Report of the Secretary General on the Plan for an Emergency International United Nations Force, U.N. GeN. Ass. OfF. Rec. Ist Emergency Spec. Sess. Annexes, Agenda Item No. 5, at $19(A / 3302$ and Adds, $1-30)(1956)$.

24 There were, however, some important refinements. The UNEF contingent was recruited on the principle of universality but exclusion of nationals of the Big Five powers. The Secretary-General even "politely rebuffed a British-French effort to take part in deciding the composition of the staff and contingents." W. Frye, A United Nations Peace Force xI (1957). See also Second and Final Report of the Secretary-General, supra note 23, at 4; and Resolution 10oo, U.N. GEN. Ass. OFp. REc. Ist Emergency Spec. Sess., Supp. No. I, at 2 (A/3354) (1956), which specifically excludes recruitment of officers or troops from "the permanent members of the Security Council." The same principle was followed in organizing ONUC with the significant added qualifications that the contingent would not include units "from any country which, because of its geographical position or for other reasons, might be considered as possibly having a special interest in the situation. . . " ANNUAL REPorr 2.

${ }^{28}$ Second and Final Report of the Secretary-General, supra note 23 , at 4 .

2 FrYe, op. cit. supra note 24 , at 16. ${ }^{27}$ Id. at $23-31$.

92 Report of the Secretary-General on Basic Points for the Presence and Functioning in Egypt of the United Nations Emergency Force, Nov. 20, I956, U.N. GeN. Ass. Off. Rec. IIth Sess., Annexes, Agenda Item No. 66, at 9 (A/3375 and Annex Aide-Memoire) (1956). 
Nations Charter, which defines powers of the Security Council as regards "threats to the peace, breaches of the peace, and acts of aggression." Decisions taken by the Security Council are not mere recommendations; they are compulsory mandates which the members of the United Nations "agree to accept and carry out."20 If the Congo was not under this obligation in July, it clearly has been since its admission to membership in September, 1960. Its adherence to the decisions of the Security Council is therefore not based on contract but upon legislation. This makes an important difference: ( $\mathrm{I}$ ) a legislative intervention can be altered legislatively, while a contract can only be altered by the consent of the parties; and (2) a legislative intervention cannot be terminated as a consensual relationship might, by the withdrawal of the host country's consent. ${ }^{30}$

The practical differences between the two relationships are readily apparent. The United Nations went into the Congo to provide technical assistance in consultation with the Congolese Government. But, unlike UNEF, it was not there on suffrance. Right from its inception, "the Organization reserved for itself the authority to decide on the composition of the Force" although it "should take fully into account the view of the host Government."31 Moreover,

although the United Nations Force under the resolution is dispatched to the Congo at the request of the Government and will be present in the Congo with its consent, and although it may be considered as serving as an arm of the Government for the maintenance of order and protection of life-tasks which naturally belong to the national authorities and which will pass to such authorities as soon as, in the view of the Government, they are sufficiently firmly established-the Force is necessarily under the exclusive command of the United Nations. . . . The Force is thus not under the orders of the Government nor can it ... be permitted to become a party to any internal conflict.

Further, because the Congo is obliged "when exercising its sovereign right with regard to the presence of the Force [to] be guided by good faith in the interpretation of the purposes of the Force," it follows (as a matter of right, not of agreement) that

the United Nations activity should have freedom of movement within its area of operations and all such facilities regarding access to that area and communications as are necessary for a successful accomplishment of the task. ${ }^{32}$

${ }^{20}$ U.N. Charter 2rt. 25. It is not clear just which articles of the Charter constitute the authority for the Security Council's action. However, the International Court has recently held that "the operations known as UNEF and ONUC were not enforcement actions within the compass of Chapter VII . ..." Certain Expenses of the United Nations (U.N. Charter art. 17, para. 2), Advisory Opinion of 20 July 1962: [1962] I.C.]. Rep. 157, 166. Thus the Security Council must be deemed to have acted under article 40 , which is in chapter VII but is not an enforcement measure, being more in the nature of an interlocutory order.

${ }^{80}$ Even Egypt, however, in its "contract" with the United Nations agreed, however vaguely, that "the United Nations understanding this to correspond to the wishes of the Government of Egypt, reaffirms its willingness to maintain the UNEF until its task is completed."

"1 ANwUal Report 2. "While it is for the United Nations alone to decide on the composition of military elements sent to a country, the United Nations should, in deciding on composition, take fully into account the viewpoint of the host Government as one of the most serious factors which should guide the recruitment of personnel." U.N. Doc. No. S/4389, at 4 .

${ }^{s 8}$ U.N. Doc. No. S/4389, at 3 . 
A general agreement with the Congolese authorities was in fact obtained, but only some days after troops had begun to land, and it was needed, according to the United Nations, not for jurisdiction, but for the more limited purpose of "specifying what is to be considered the area of operations." ${ }^{33}$ Even before any such specifications were agreed upon, the United Nations had already placed Ndjili airfield at Léopoldville under United Nations control, assuming all responsibility for military, administrative, and transport staffing of its facilities. ${ }^{34}$

At no time during the formation of the United Nations Force or thereafter were the United Nations obliged to act as if the ONUC operation were a consensual undertaking cut to the pattern of UNEF. Quite the contrary. When the Congolese Government demanded the withdrawal of Ghanaian troops, they were rebuffed. When the.Central Government demanded to be associated with the United Nations entry into Elizabethville, the Secretary General

informed the Congolese Prime Minister of the resolution adopted that day by the (Security) Council and drew his attention to the fact that it was mandatory, in particular where, on the basis of Article 49 of the Charter, it requested the cooperation of all Member States....

He also informed President Kasavubu "that there could be no question of conditions as of an agreement on that matter...."35 Similarly, when President Kasavubu, on January 7 and 14, I96I requested the recall of the United Nations Special Representative, Ambassador Dayal, who was in field command of the entire ONUC, the Secretary General drew attention to the fact that "the Special Representative was not a diplomatic representative accredited to the Congolese Government but a senior official of the Secretariat" and that it was "impossible . . . to accede to the demand...."36 In several important instances, also, the Secretary General authorized the use of force against the Government of the Congo-once to protect the territorial immunity of the Ghanaian Embassy in Léopoldville ${ }^{37}$ and once to defend ONUC's exclusive control of the key port of Matadi. ${ }^{38}$ The United Nations also cordoned off certain areas in Léopoldville, Stanleyville, Bukavu, Goma, and in other parts of Kivu, Kasai, and Katanga as "neutral zones" for political refugees, without obtaining the prior consent-indeed, over the objections-of the Congo Government. ${ }^{30}$

${ }^{83} \mathrm{Ibid}$. For text of the preliminary agreement, see U.N. Doc. No. S/4389/Add.5. The text of the final agreement of Nov. 27, 196I is contained in U.N. Doc. Nos. S/5004 and A/4986.

${ }^{34}$ U.N. Doc. No. S/4389/Add.r.

${ }^{36}$ ANNUAL Report 7.

${ }^{86} \mathrm{Id}$. at 33 .

${ }^{87}$ On Nov. 15,1960 , M. Lovelace Mensah, third secretary of the Ghanaian Embassy in Léopoldville, was arrested by Colonel Mobutu's troops. He had allegedly been carrying funds to M. Lumumba-an allegation denied by the Ghanaians. An expulsion order was issued to Mr. Nathaniel Welbeck, the Ghanaian charge d'affaires, but was ignored. After waiting three days, the Congolese troops set upon the Embassy around which ONUC troops had been posted. Both Mr. Hammarskjold and Mr. Bunche agreed with Mr. Dayal to uphold the doctrine of inviolability of embassies as against the doctrine of persona non grata. Four Congolese, including the deputy chief of staff, were killed in the engagement. See Annuar Report 24.

${ }^{38}$ The Matadi incidents and similar efforts by Central Government troops to oust the United Nations from control of Ndjili airfield and other key installations is discussed in ANNUnL REPORT 37-39.

3o ANnual Report 37-38. 
The implications of a mandatory, nonconsensual United Nations action of the ONUC stripe are far more important than the scattered incidents which attest to its mandatory nature. It is most important, for example, that the ONUC Operation may-as indeed from the very beginning, we have observed, it did-depart from the terms of the inceptive request of the host country. These departures and innovations mounted as the nature of the political crisis changed, and the consent of the Congolese authorities was never regarded, by any member of the United Nations with the possible exception of France, as a prerequisite to altering the nature of the intervention. Thus, the second Security Resolution, that of July 22, I960, for the first time impliedly authorized the ONUC to restore "law and order in the Republic of the Congo"40 - and without further caveat about acting "in consultation with the Government of the Congo." As late as August 9, the Security Council still reaffirmed that "the United Nations Force in the Congo will not be a party to, or in any way intervene in or be used to influence the outcome of any internal conflict." ${ }^{241}$

This policy of laissez faire towards the civil war was based on the illusion that once the Belgians left of their own accord, the crisis would be over, an illusion captured in the Secretary General's instructions to ONUC troops: ". . . [M]en engaged in the operation may never take the initiative in the use of armed force, but are [only] entitled to respond with force to an attack with arms. . . .42 It was under those terms that the United Nations entered both the Congo and, on August I2, the "independent state" of Katanga. Just prior to the August landing in Elizabethville the Secretary General also reiterated that the resolution of August 9, instructing ONUC to enter Katanga, did not authorize it "to intervene with armed troops in an internal conflict. ..." 43 Yet, on February 21, I96r, the Security Council reacted to the changed circumstances of $M$. Lumumba's murder by authorizing the United Nations to "use force, if necessary, in the last resort [to] prevent the occurrence of civil war" and bring about "the halting of all military operations." also impliedly authorized ONUC to promote certain objectives strongly resisted by the Central Government, such as the "convening of the Parliament" and the reorganization of the army (ANC)..$^{45}$

An equally radical departure is the authorization, ${ }^{46}$ in the Security Council resolution of November $24,196 \mathrm{x}$, for

the Secretary-General to take vigorous action, including the use of a requisite measure of force, if necessary, for the immediate apprehension, detention pending legal action and/or deportation of all foreign military and para-military personnel and political advisers not under United Nations Command. . . .

Although this was the first specific authority for the use of force against foreign political advisers, it was not by any means the beginning of the United Nations

\footnotetext{
${ }^{10}$ U.N. Doc. No. $S / 4405$.

${ }^{12}$ U.N. Doc. No. S/4389 at 5.

4 U.N. Doc. No. S/474I.

«I.N. Doc. No. S/4424.

18 U.N. Doc. No. S/PV.887 at I7.

${ }^{15}$ Ibid. See also Annunl Report 38.
}

"U.N. Doc. No. S/5002. For Congolese Government opposition to this, see ANNual Report 38. 
campaign to eliminate this non-military influence from the Government of Katanga and from the Central Government.

In his report of November 2, Ig60, Special Representative Dayal had already sighted the conflict between ONUC and the Belgian political advisers-men, generally, of undersecretarial or chefs de cabinet rank who had returned in large numbers after the first wave of terror had receded. ${ }^{47}$ "As a result," Ambassador Dayal complained, ${ }^{48}$

the task of ONUC has been made more difficult ... cooperation with ONUC, vital to its smooth functioning, has been hampered in various ways by high-ranking Belgians. United Nations documents and reports have frequently been withheld from the Congolese officials in the ministries and propaganda has been engineered regarding the supposed dangers of the emergence of United Nations trusteeship....

The motives and activities of a significant portion of these returning officials appears to be clearly at variance with the principles of the General Assembly resolution and the ONUC's basic objectives. ${ }^{49}$

It was not, however, until the death of Patrice Lumumba with which, rightly or wrongly, Belgian advisers were popularly associated ${ }^{50}$ that the Security Council for the first time urged "the immediate withdrawal of and evacuation from the Congo of all Belgian and other ... political advisers not under the United Nations Command." $" 51$

The Central Government of the Congo was little more pleased than the Government of Katanga ${ }^{52}$ by these new departures in United Nations policy. Nevertheless, on April I7, 196I, President Kasavubu reluctantly signed an "agreement in principle" with the Secretary-General acquiescing in "the elimination of all deleterious foreign influences" in the Central Government and also to United Nations-assisted reorganization of the $\mathrm{ANC}^{53}$ Neither provision has ever been completely implemented although pressure in that direction is still being exerted.

In these important matters the United Nations can alter, and in practice has unilaterally altered, the original terms of its Congo intervention (if "unilateral" is a word to describe the actions of more than roo nations acting in concert). It also follows that nothing short of a decision to do so by the Organization can bring the intervention to an end. This despite the terms of the original resolution ${ }^{64}$ to the effect that United Nations intervention will continue only until "the national security forces may be able, in the opinion of the Government, to meet fully their

47 The Belgian population of the Congo which had fallen from 100,000 to 20,000 in the autumn, had again doubled by February 196r. The Times (London) Feb. 24, 196r; The Observer, Feb. 19, 196r.

${ }^{* 8}$ Second Progress Report to the Secretary-General of his Special Representative, Nov. 2, 1960, U.N. Doc. No. $\mathrm{S} / 4557$ at $16-18$.

${ }^{10}$ Id. art. 9 .

${ }^{\text {to }}$ See Report of the Commission of Investigation Established Under the Terms of General Assembly Resolution I601 (XV), Nov. II, I96o, U.N. Doc. Nos. A/4964 and S/4976.

${ }^{51}$ Resolution of Feb. 2I, I96I, U.N. Doc. No. S/474r.

63 ANNUAl Report 37-4I.

5 U.N. Doc. No. S/4387. (Emphasis added.) 
tasks." In fact, of course, and despite occasioned rough passage in the relations between the ONUC and the Congo, no such request has ever been made by the Central Government.

Indeed, during the political interregnum between Premiers Lumumba and Adoula it is doubtful that there was a government competent to make such a request. The fact, in either case, remains that the ONUC, although it incorporated the Congolese request in its initial enabling resolution, is an exercise of United Nations jurisdiction under chapter seven of the Charter, which is not subject to termination at the request of the host state. This, again, was not true of UNEF, and UNEF's agreement with Egypt deliberately left unclear the question of "winding-up." "T5 The ONUC agreement, however, is quite specific: ${ }^{58}$

The United Nations reaffirms, considering it to be in accordance with the wishes of the Government of the Republic of the Congo, that it is prepared to maintain the United Nations Force in the Congo until such time as it deems the latter's task to have been fully accomplished.

The pronoun "it" obviously refers solely to the United Nations.

It is therefore apparent that a nation which invites the United Nations to participate in a play on its stage, cannot by itself ring down the curtain. It cannot bind the legislative power of the Organization to a particular method or duration of intervention. In such a situation, the United Nations intervenes as of right. By assisting or requesting the intervention the host-state may gain bargaining leverage in its day-to-day relations with an administration which will travel far to achieve its given objectives by peaceful cooperation-but it cannot alter the legal status of the intervention.

Yet these legalities may be somewhat misleading. It is true in law that the United Nations intervened on the basis of its Charter powers and not, as in UNEF, on the basis of the request or consent of the host-state. On the other hand, it is equally true that in practice, an intervention such as that of ONUC would probably never have occurred had the Congo not issued an invitation. Aside from the logistic difficulties of intervening in opposition to the host state, there is the great political unlikelihood of enlisting Afro-Asian cooperation for a venture which, without the Congo's invitation, would have seemed "neo-colonial." In comparable future situations, states may well prefer to take advantage of an intervention sponsored by the General Assembly, where an invitation is not a carte blanche, in preference to the services of the Security Council. Attractive as such an idea may sound, it should nevertheless be remembered that, had the United Nations had to act in the Congo on the basis of consent, it might well not have been able to act at all to prevent bloody civil war.

tos See supra note 30 .

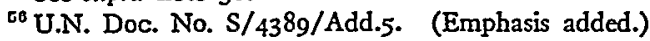


United Nations Jurssdiction and Domestic JuRisdiction: The Legar Basis for InTervention

In a sense, the world must thank God for the Belgians, for had they not intervened, the United Nations would certainly not have had so clear a jurisdictional basis for its interposition. The Belgians added the essential foreign ingredient which made the "situation" one of international peace and security as required by article thirty-nine of the United Nations Charter.

The original resolution of July 14 , Ig60, makes no reference to any particular authorizing paragraphs of the Charter, nor have subsequent resolutions done so. The Secretary General, however, has inclined to the view that "the Council's resolutions could be regarded as implicitly adopted under Article 40 and as based on an implicit finding under Article 39."57 In any event, there is general agreement that no action authorized by the Security Council to date (with the possible contingent exception of one provision in the resolution of September 24, I961 $)^{58}$ could be regarded as an "enforcement measure" under chapter seven. Action under article forty is not such a measure but is, instead, comparable to a preliminary injunction. It is not an "enforcement measure" but a "provisional measure . . . without prejudice to the rights, claims or position of the parties concerned."50

This is not a purely academic difference. When the United Nations is engaged in an "enforcement measure" under chapter seven of the Charter, the fact that the object of such action ordinarily would be "essentially within the domestic jurisdiction" of the state where the action is taking place is not sufficient to bar the United Nations' right to act. ${ }^{60}$ However, if-as in the overwhelming preponderance of ONUC activities-there is not the color of an "enforcement action," the United Nations must scrupulously avoid intervention in "matters which are essentially within the domestic jurisdiction" of any state. ${ }^{61}$ This prohibition is not one to be waived even by the host state. ${ }^{62}$ A United Nations action against a matter which is essentially domestic, if it is not of such gravity as to warrant an enforcement action, is ultra vires.

So long as the Belgian armed forces continued their incursion into Congolese territory, the United Nations was obviously not intervening in an "essentially

${ }^{57}$ Annuna Report 27. See also Miller, Legal Aspects of the United Nations Action in the Congo, 55 AM. J. INT'L L. I, 4-9 (I96I).

${ }^{68}$ U.N. Doc. No. S/5002. Paragraph 9 ". . . declares full and firm support for the Central Government of the Congo, and the determination to assist that Government in accordance with the decision of the United Nations to maintain law and order and national integrity, to provide technical assistance and to implement those decisions." What does "implement those decisions" mean? If "technical assistance" here means the same as in the first resolution (U.N. Doc. No. S/4387) it may be said to authorize the use of troops against rebels.

${ }^{50}$ U.N. Charter art. 40. See note 29 supra.

${ }^{60} 1$. art. $2(7)$.

or Ibid.

${ }^{62}$ The Congolese Government has at times enacted laws which it then requests the ONUC to enforce. See, for example, the Ordinance of Aug. 24, I96r, concerning arrest of foreign mercenaries. U.N. Doc. No. S/4940/Add.I 4. 
domestic" matter. However, once the Belgian troops were gone, the United Nations, still without engaging in an "enforcement action," began to intervene quite actively in a number of other matters which were not quite so obviously or so traditionally "international." Among these, the most important is the civil war with the provinces of Katanga and Orientale. It is not enough, say the critics, that the Congolese central government has in each instance requested United Nations help. It is beyond the powers of the United Nations to respond to such a request. It is this view which motivates French reaction to the Congo operation and which occasioned a French amendment to the resolution of December $20,196 \mathrm{I}^{63}$ asking the International Court to rule explicitly on whether the expenses incurred by ONUC were ultra vires.

What it comes to is this: May the United Nations decide to help one side of a civil war against another in the absence of a foreign military element? The vast preponderance of United Nations action has not, of course, been in the nature of such action. For one thing, it is only since the resolution of November 24, Ig6r, that the Security Council has specifically authorized it, ${ }^{84}$ and then only to the ambiguous extent of rendering "technical assistance." Almost invariably, United Nations action has been motivated by the mandate to preserve "law and order" and to "prevent the occurrence of civil war." military action against the Katanga Gendarmerie beginning on December 5, Ig6r, the expressed motivation was purely defensive. "This military action," the Acting Secretary General said, ${ }^{66}$

was undertaken with the greatest reluctance, and only when it became obvious that there was no use in continued negotiations. ... The purpose of the present military operations is to regain and assure our freedom of movement, to restore law and order, and to ensure that for the future the United Nations forces and officials in Katanga are not subject to attacks; and meanwhile to react vigorously in self-defense to every assault on our present positions, by all the means available to us.

Similarly, Ambassador Stevenson has been at pains to explain that the "intention here has never been to interfere or to influence the political situation in the Congo.... The United Nations forces were attacked by Katanga forces in each case and this was a response to these attacks." ${ }^{87}$ Nevertheless, the Secretary General has also placed the general position in a somewhat different perspective, noting his instructions that everything possible must be done to avert civil war. . . . This, I believe, necessarily implies a sympathetic attitude on the part of ONUC towards the efforts of the Govern-

${ }^{03}$ Resolution 173 I (XVI) on a report of the Fifth Committee, U.N. Doc. No. A/5062. This is the resolution asking for an advisory opinion on the legal status of special assessments in relation to article 17(a) of the Charter.

o4 U.N. Doc. No. S/5002. See also, however, Assembly Resolution 1474 (ES-IV), A/L.292/Rev./I, para. 2.

${ }^{\circ 5}$ U.N. Doc. No. Res. S/474I, para. I.

oo The Congo-A Move Toward Reconciliation, 9 U.N. REv. I, 7 (I962).

${ }^{67}$ Hearings Before the Senate Comm. on Foreign Relations on S. 2768, Purchase of United Nations Bonds, $87^{\text {th }}$ Cong., 2 d Sess. 89 ( 1962 ). 
ment to suppress all armed activities against the Central Government and secessionist activities. $^{68}$

A clearer example of United Nations intervention in a civil war situation than that afforded by the action in Katanga is the use of force on behalf of the Central Government against the regime in Orientale Province. Excerpts of the Report of the United Nations Officer in Charge are instructive: ${ }^{60}$

During the night of January I2-13 the Gendarmerie were mobilized and took position around Mr. Gizenga's residence and in their own camp (Camp Ketele). The Gendarmerie also erected roadblocks outside Mr. Gizenga's house and were reported to have arrested their own officers, who were being detained in Camp Ketele.

During the same night General Lundula's Prevote militaire and para-commandos took position around General Lundula's own headquarters.

In the morning of January $\mathrm{I}_{3}$ the President of the provincial government, Mr. Simon Losala, made a radio broadcast in which he indicated that Mr. Gizenga must leave Stanleyville and that the province would follow the Central Government. Mr. Gizenga was also told that he would have to take all the consequences in the event trouble broke out.

At approximately 9:00 o'clock in the morning of January $\mathrm{I}_{3}$ fighting broke out at Camp Ketele between the Gendarmerie and General Lundula's men which resulted in the death of eight gendarmes and six ANC soldiers. While the fight was going on, General Lundula requested that the United Nations should assist in restoring law and order by disarming the gendarmes.

Prime Minister Adoula was immediately informed of the fighting which had taken place and of the request for ONUC assistance submitted by General Lundula. . . .

The two letters were relayed immediately to the Acting Secretary-General who confirmed that the assistance requested by the Prime Minister could be afforded within the framework of ONUC's mandate to assist the Central Government in the maintenance of law and order and in the prevention of civil war. These instructions were conveyed to the ONUC Contingent Commander in Stanleyville in the evening of January 13. At that time, the ONUC troops in Stanleyville totalled some 980 men composed of the twenty-sixth Ethiopian battalion, a small detachment from the thirty-fifth Ethiopian battalion as well as various elements of an Ethiopian brigade command. Their Commanding Officer, Colonel Teshome, indicated that General Lundula had under his command five companies of ANC, two MP companies and two companies of paracommandos. The municipal police was also reported to be supporting General Lundula. The ONUC Contingent Commander was confident that there were thus sufficient troops to carry out the mandate, if required by developments in the situation.

A report received from the ONUC Chief Civilian Representative in Stanleyville indicated that on the morning of January $\mathrm{r}_{4}$ a conference had taken place in General Lundula's headquarters which was attended by a delegation from the gendarmes guarding Mr. Gizenga's residence and by ONUC representatives. The gendarmes were given thirty minutes by General Lundula to surrender and lay down their weapons. Accordingly, thirty-four gendarmes laid down their arms. During this conference, fighting was resumed at Camp Ketele and mortars were used. The fight lasted about half an hour and involved gendarmes and the soldiers of General Lundula.

${ }^{68}$ U.N. Doc. No. S/PV.892 at 7r. (Emphasis added.)

${ }^{80}$ Report of the Officer-in-Charge of the United Nations Operation in the Congo to the SecretaryGeneral, Jan. 20, 1962, U.N. Doc. No. 5/5053/Add.I at 3-5. 
The Gendarmerie Commander, one gendarmerie captain and a gendarmerie warrant officer, who had been arrested by their own troops, were liberated. They had been severely ill-treated and were taken immediately to the ONUC hospital.

Still in the morning of January 14, Mr. Gizenga, with whom the United Nations representatives were in close contact, requested ONUC to convey a telegram to the Prime Minister. ... .

During January I4 ONUC troops continued to assist those of General Lundula in disarming the Gendarmerie. By the end of the day the whole of the Gendarmerie, with the exception of approximately fifty men, had been disarmed. The ONUC military commander reported that during the whole operation only one ONUC platoon had been engaged which had not fired a single shot. Most of the prisoners were under ONUC protection, with the exception of one company which had stayed in its camp under ANC guard.

On the evening of January $\mathrm{I}_{4}$, General Lundula sent a message to Prime Minister Adoula.

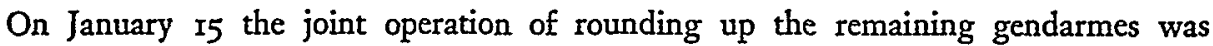
continued, and a further eighteen gendarmes were disarmed. Some of them were apprehended wearing civilian clothes. The situation in town was reported to be calm with ONUC troops continuing to enforce, in cooperation with General Lundula's troops, full security measures with respect to public law and order. In the afternoon of January 15th, Parliament in Leopoldville adopted the motion tabled on January $13^{\text {th }}$ and thus endorsed the removal of Mr. Gizenga from his post of Vice-Prime Minister of the Central Government. Votes were cast as follows: sixty-seven for, one against, and four abstentions....

Although the Stanleyville action, too, can be explained in terms of preserving "law and order" is is undisguisedly an intervention with decisive weight on the side of the central authorities in a situation of civil insurrection. Yet there is nothing particularly startling ${ }^{\mathbf{7 0}}$ about the proposition that the jurisdiction of the United Nations extends to such an intervention and that a civil war, although fought entirely in the Congo by Congolese, may still involve consequences not "essentially domestic" in their effect. The United Nations continues to be engaged in an interposition in the Congo, although it is no longer primarily one against an actual invasion such as faced UNEF, or ONUC during its inception. It has instead become an interposition against domestic forces which carry into a purely domestic war the talismen, the aspirations, and the indirect support of parties to the "cold war." It is an interposition against foreign "volunteers" who in the Congo, as in Korea, provided the brains and brawn of the conflict. It is an interposition against foreign economic interests which provide the financing for insurrection. Most important, it is an interposition against a chaos which, if allowed to go unchecked, would have made the direct interposition of cold-war forces inevitable.

This constitutes a notable, but sensible and historically consistent diminution of the meaning of "domestic jurisdiction" as used in article $2(7)$ of the Charter.

${ }^{70}$.C. I L. Oppenheim, International Law 290-94 (8th ed., Lauterpacht 1955), and especially the discussion of the Trail Smelter Arbitration of r938, at $29 \mathrm{r}$ n.2. Also Emperor of Austria v. Day and Kossuth, 2 Giff. 628, 66 Eng. Rep. 263 (V.C. I86I). 
There are two other bases on which United Nations jurisdiction has been invoked to restrict freedom of action of Congolese authorities. On two occasions, once in September 1960, when Lumumbist Lulua troops slaughtered one thousand Kasai Balubas, and again, when in March I96r, the Lunda troops of President Tshombe launched their massive attack on the Katanga Balubas, the United Nations Command justified intervention by invoking, inter alia, the Genocide Convention. ${ }^{71}$ This is of particular importance to the development of United Nations law, since hostility between tribes is one of the more omnipresent shadows lingering over much of newlyindependent Africa.

Finally, the United Nations has, on a number of occasions, intervened in otherwise "domestic" matters to uphold human rights and fundamental freedoms. ${ }^{72}$ In February rg6r, Ambassador Dayal on this basis intervened with the Gizenga authorities in Stanleyville against a proposed $\$ 600$ levy on every Belgian male over the age of twenty-one. The same authority, supplementing the "law and order" mandate, was cited to justify the establishment of neutral or "protected" areas in the towns, and to grant protection and asylum to political refugees-even, on occasion, in defiance of arrest warrants issued by the Central Government. ${ }^{73}$

\section{IV}

\section{The United Nations and Constitutional Law}

Right from the start of its intervention, ONUC faced the collapse of constitutional government in the Congo. On Monday, July II, 1960, the Katanga legislature proclaimed its independence and secession, demanding diplomatic recognition and admission to the United Nations. In dealing with this alleged "right of selfdetermination" the task of the United Nations was substantially simplified by the fact that not one state has extended diplomatic recognition to Katanga. The United Nations Operation followed the unanimous precedent of the member states in refusing to treat the Tshombe government as sovereign. In this it was supported by article six of the Loi fondamentale, which specifically forbids secession. It was also supported by the legal circumstances which surround the formation of the Tshombe government. Articles IIO and II 4 of the Loi had emerged from the preindependence Round Table Conference with an agreed provision making a two-thirds quorum in provincial assemblies prerequisite to the election of provincial governments. The outcome of the Katangese provincial election had, however, given M. Tshombe a parliamentary following of only twenty-four to twenty-two for the

\footnotetext{
"2 ANNuna Report II and 35. For text of the Genocide Convention, see Resolution No. 260 (III), Gen. Ass. Off. Rec. Res. at 1744, U.N. Doc. No. A/8ro.

${ }^{2}$ See International Declaration of Human Rights adopted by the General Assembly on Dec. 10, I948, U.N. Doc. No. A/8ro, at 7 I.

${ }^{73}$ AnnUal Report 4I. For description of the protection given to M. Lumumba, see Report of the Commission on Investigation, Nov. II, I96I, U.N. Doc. No. A/4964 at 13-16; also Second Progress Report to the Secretary-General from his Special Representative, Nov. 2, I960, U.N. Doc. No. S/4557, in Security Council OfF. Rec. Isth year, Supp. Oct.-Dec. 1960, at 12.
} 
Opposition Balubakat party (with thirteen Tshombe-inclined Independents). By boycotting the provincial sittings, Balubakat was able to prevent the lawful election of M. Tshombe's government. Thereupon, two weeks before independence, Belgium unilaterally took it upon itself to repeal the two-thirds quorum provision. ${ }^{74}$

Therefore, the legal status of Katangese independence is not without blemish. This fact alone could not, however, be conclusive for ONUC. The right of revolution, of "self-determination," is obviously not primarily subject to the standard of domestic legality. Neither, however, is it an absolute right in international law. The Austrian State Treaty, for example, specifically forbids Austria to "selfdetermine" itself into union with Germany. ${ }^{75}$ The United Nations has similarly refused to support cultural autonomy for the people of Alto-Adige and, more significantly, has specifically rejected self-determination as a course of development for the Ewe tribe of the British Togoland Trusteeship. ${ }^{78}$ The concept of "self-determination," which is merely one of the purposes of the United Nations, co-exists, for example, with respect for "territorial integrity"77 as well as with "political, economic, social and educational advancement."78 In practice, the United Nations has with consistency opposed the formation of small, economically unviable entitiesthe most recent example being the efforts exerted by the World Organization to prevent the total separation of the Kingdoms of Ruanda and Urundi. ${ }^{79}$

In the case of Katanga, the impact which secession would have on the political, economic, social and educational advancement of the Congo as a whole may best be judged by the fact that one Katangese corporation, the Union Minière du Haut Katanga, before independence supplied the central exchequer of the Congo with approximately one third its tax revenues, and even in Ig60, continued to pay some $\$ 52$ million in taxes and dividends to the government. ${ }^{80}$ United Nations jurisprudence has developed a consistent practice of limiting the "right" of self-determination to overseas ${ }^{81}$ colonial possessions and to instances in which independence is economically and socially feasible. It is in this light that one must read the Security Council's eloquent resolution of November 24, $196 \mathrm{r}$, where it declares that "all secessionist activities against the Republic of the Congo are contrary to the Loi fondamentale and Security Council decisions" and "specifically demands that such activities which are now taking place in Katanga shall cease forthwith." 82

A much more difficult legal problem arose out of the disintegration of the central government of the Congo. The United Nations intervention had been authorized

\footnotetext{
74 Republic of the Congo, Ministry of Foreign Affairs, Document Division, The Province of Katanga and Congolese Independence 9-i i (r962).

${ }^{75}$ State Treaty for the Re-establishment of an Independent and Democratic Austria, 217 U.N.T.S. 225 (1955).

${ }^{70}$ An abridged account of the lengthy considerations preceding the decision to reject the Ewe claim may be found in Louis B. Sohn, Cases and Materials on UNited Nations Law 742-72 (I956).

${ }^{77}$ U.N. Charter art. 2(4). ${ }^{78}$ Id. art. $73(\mathrm{a})$.

${ }^{70}$ See $A$ Formula for Ruanda-Urundi, 9 U.N. Rev. 6 (1962). See also id. at 63.

${ }^{80}$ N.Y. Times, Dec. 12, 196x.

${ }^{81}$ U.N. Doc. No. A/4526, Part V(B). $\quad{ }^{82}$ U.N. Doc. No. S/5002.
} 
to supply military assistance to "the Government of the Congo" and to do so "in consultation with the Government of the Congo."83 The entire operation predicated a cooperative venture between the ONUC and a legally-constituted and accepted Central Government of the Congo. When on September 5, Ig6o, such a government ceased to exist, the United Nations, having already committed some I8,000 officers and men from twenty-nine nations to the ONUC undertaking, were placed in an unexpectedly awkward position. ${ }^{84}$ Which "Government of the Congo" was to be assisted, whose "law and order" was to be enforced, what "national security" was to be maintained?

In this case, the United Nations could not rely upon purely behaviorist international law. Some nations, after the fall of Premier Lumumba, extended recognition to the government of his vice-Premier, Gizenga, at Stanleyville: among them the communist nations of Eastern Europe, as well as Morocco, Mali, Cuba, Ghana, Outer Mongolia, Guinea, Yugoslavia, Indonesia, and Ceylon. Other states maintained relations with the regime at Léopoldville, and India maintained diplomatic relations with neither. ${ }^{85}$ Whereas in the case of non-recognition of Katanga, ONUC could observe and follow the consistent behavior of its member states, there was no such clear guidance to help it sort out the problem of the rival central governments.

It therefore became necessary for the United Nations, relying on its "law and order" mandate, to develop a certain expertise in Congolese constitutional law in order to interpret the legality of the events following the dismissal by President Kasavubu on September 5 of his Prime Minister, Lumumba. According to the Loi fondamentale, ${ }^{86}$ the "Government of the Congo is composed of the Prime Minister and the Ministers."87 It specifically does not include the President who, as Chief of State, is a separate "institution." State designates and revokes the Prime Minister and his Ministers" 80 but if, as occurred on September 5, the Chief of State does discharge the Government, a new one must present itself to Parliament for a vote of confidence. ${ }^{00}$ Between the time of M. Lumumba's dismissal and the vote of confidence given by the reassembled Parliament to the Government of $\mathrm{M}$. Adoula, ${ }^{81}$ no constitutional government functioned in the Congo. ${ }^{92}$ There was, in other words, a governmental interregnum of eleven months.

\footnotetext{
${ }^{83}$ Resolution of July I4, I960, U.N. Doc. No. S/4387.

si Second Progress Report, U.N. Doc. No. S/4557, at 26.

${ }^{85}$ N.Y. Times, Feb. 19, 1961, \$ I, p. I, col. 7; p. I4, cols. I-7.

${ }^{80} \mathrm{Law}$ of May 19, I960; [1960] Moniteur BeLce 3988. This law had not, incidentally, been subject to adoption as a national constitution by the Congolese Parliament and was therefore itself only the "best thing available" for assessing the legalities of the constitutional crisis.

${ }^{87}$ Loi fondamentale art. $35 . \quad{ }^{88}$ Id. art. 8, lit. a.

${ }^{90} \mathrm{i} \tilde{d}$. art. 42.

${ }^{\circ 1}$ U.N. Doc. No. S/4913, at 2 .

92 The United Nations was not only faced with the delicate task of interpreting the Loi fondamentale but also of political events which purported to bear on that interpretation. Thus, on Sept. I4, for example, the Congolese Parliament held its last session before the interregnum, a joint meeting at which "full powers" were voted to M. Lumumba. According to the ONUC Special Representative, however, the decision "was somewhat uncertain as to both substance and count." ANNuAl Rerort 13. The
} 
What was the position of ONUC during this period towards Congolese legal authority? There was, of course, no shortage of contenders for the position vacated by M. Lumumba. First, President Kasavubu named Joseph Ileo to head a new Government. On September 14, I960, Col. Mobutu announced the suspension of constitutional government, and that "in view of the struggle going on between two opposing governments," ${ }^{\prime 93}$ a collège d'universitaires would take charge of the management of the ministerial departments. The appointment of these "Commissioners General" was ratified by presidential decree on September 20, but the earlier presidential decree designating a government under $M$. Ileo was never rescinded. ${ }^{94}$ Furthermore, Colonel Mobutu let it be known that he objected to the President's participation in legitimizing his Government, as he had "neutralized political personalities. ${ }^{.05}$

During most of the ensuing period the Mobutu government was never able to extend its control much beyond a 70-mile perimeter around Léopoldville. Twentysix officers of the Congolese National Army, who were sent on a mission of reconciliation to the six provinces, were ultimately discharged from the army without completing the mission on the ground that they had been "indoctrinated" in the course of carrying it out. ${ }^{96}$ Meanwhile, M. Lumumba, who continued to occupy the residence of the Prime Minister, surrounded by concentric rings of ONUC and ANC troops, showed up the tenuous control of Colonel Mobutu even in Léopoldville by emerging on occasion to make tours of the city or to hold a press conference. After his attempted escape, $M$. Lumumba was transferred to the maximum security of the Thysville ANC barracks, but even here he was reportedly soon enjoying the run of the camp and indoctrinating the troops. This led to the former Premier's fateful further transfer to Katanga.

An earlier Secretary-General had, in a legal memorandum, defined a test for deciding whether to accredit the United Nations delegates of a government whose status was in doubt: $:^{27}$

The question at issue should be which of these ... governments in fact is in a position to employ the resources and direct the people of the state in fulfillment of the obligations of membership. In essence, this means an inquiry as to whether the government exercises effective authority within the territory of the state and is habitually obeyed by the bulk of the population.

Obviously, this does not describe the authority of any government in the Congo, including that of Colonel Mobutu, during the interregnum.

New York Times reported the Secretary-General as declaring that, according to eye witnesses, "in the hall of the Chamber of Deputies there were some scores of the ANC [army] present-then loyal to Mr. Lumumba-during the debate and voting. They were fully armed with rifles and sub-machine guns." N.Y. Times, Dec. 14 , r960, p. r, cols. 6-7.

os Second Interim Report of the Special Representative, U.N. Doc. No. S/4557, at I0.

os Id. at II.

${ }^{\circ}$ Ibid.

${ }^{\circ}$ Ibid.

${ }^{\circ 7}$ Memorandum prepared by the Secretary-General, February r950, Security Counciz OfF. Rec. 5th year, Supp. Jan.-May $1950(S / 1466)$ at $18-23$ (1950). 
The United Nations acted in accordance with this formula. "Committed to the principle of neutrality, it could not have chosen between rival governments, nor could it respond to the continuing appeals that it install one or another government." 98 Committed to the principle of "law and order," it could not give full de jure recognition to the perpetrators of a military coup. On the other hand, it was quite prepared to establish de facto relations with Colonel Mobutu's Government in so far as it exercised de facto control. Ambassador Dayal laid down the policy: ${ }^{99}$

ONUC ... while taking no position on the legality of the constitutional decrec-law of October II, rg6o creating the Council of Commissioners-General, has continued to follow its policy of dealing, in routine matters, with whatever authority it finds in the ministerial chairs.

It also continued to recognize the legal position of M. Kasavubu as Head of State ${ }^{100}$ and Colonel Mobutu as Chief of Staff ${ }^{101}$-matters about which there was little legal controversy.

On the other hand, in areas which were clearly not within the de facto control of the Mobutu government, the United Nations carried on technical relations with whatever authority was in control, ${ }^{102}$ meanwhile bending every effort to bring about national reconciliation by means of reconvening Parliament and promoting the election of a truly national government.

That was accomplished, with the United Nations providing the essential safeguards, ${ }^{103}$ on July 22 , Ig6r.

${ }^{88}$ Second Progress Report of the Special Representative, U.N. Doc. No. S/4557, at 14 .

${ }^{90}$ Ibid. ${ }^{100}$ Ibid. ${ }^{101}$ Ibid.

${ }^{103}$ For example, Exchange of Messages Between the Secretary-General and Mr. Tshombe, U.N. Doo. No. S/4557, Annex B.

${ }^{102}$ U.N. Doc. No. $S / 484$ I. 